Sains Malaysiana 48(11)(2019): 2451-2462

http://dx.doi.org/10.17576/jsm-2019-4811-15

\title{
Physico-chemical Characterisation and Potential Health Benefit of the Hulu Langat Hot Spring in Selangor, Malaysia
}

(Pencirian Fiziko-kimia dan Potensi Manfaat Kesihatan bagi Mata Air Panas Hulu Langat Selangor, Malaysia)

\author{
NORBERT Simon*, TANOt UnJah, MUZAFFAR YUSRY \& MUHAMmad ASHAHADI DZULKAFLi
}

\begin{abstract}
Geotourism is a means in geology that contributes to one of the 17 sustainable development goals (SDGs). One of the key areas in geology that can contribute to geotourism activities is hot spring exploration. This study, therefore explores hot springs in Hulu Langat, Selangor for their potential in geotourism based on their physico-chemical properties and their attributed health benefits potential. These renowned hot springs are Batu 16, Dusun Tua, National Youth Training Institute (IKBN), Sg. Serai, and Sg. Lalang. Despite their popularity among tourists, their health benefits potential remain unclear. Therefore, the physico-chemical properties of these hot springs and their potential health benefits as indicated by the abundance of trace elements in each site will be determined in this study. The temperature $\left({ }^{\circ} \mathrm{C}\right)$, conductivity ( $\mu$ s/ $\mathrm{cm})$, total dissolved solid $(\mathrm{mg} / \mathrm{L})$, salinity (ppt), dissolved oxygen $(\mathrm{mg} / \mathrm{L})$ and $\mathrm{pH}$ values of the hot springs have been measured in-situ, and the concentrations of trace elements ( $\mathrm{Si}, \mathrm{Li}, \mathrm{Fe}, \mathrm{Pb}, \mathrm{Mn}, \mathrm{Ni}, \mathrm{Se}, \mathrm{Ag}, \mathrm{Na}, \mathrm{Zn}, \mathrm{K}, \mathrm{Mg}, \mathrm{Ca}, \mathrm{Al}, \mathrm{As}, \mathrm{Ba}$, $\mathrm{Cd}, \mathrm{Cr}$ and $\mathrm{Cu}$ ) in hot springs water have been determined in the laboratory. Based on the in-situ measurement results, the hot springs are classified according to their $\mathrm{pH}$ and temperature. The $\mathrm{pH}$ value range from 6.83-8.71 shows that these hot springs are neutral to weak alkaline. The lowest temperature $\left(40.47^{\circ} \mathrm{C}\right)$ has been recorded in Dusun Tua hot spring, whereas the highest temperatures $\left(70.41-74.03^{\circ} \mathrm{C}\right)$ have been observed in IKBN hot springs. High concentrations of $\mathrm{Si}, \mathrm{Li}, \mathrm{Na}, \mathrm{K}, \mathrm{As}$ and $\mathrm{Cu}$ are found in Batu 16 hot spring. The concentrations of Fe and Ca are higher in Sg. Serai and $\mathrm{Sg}$. Lalang hot springs, and the highest $K$ concentration is found in Dusun Tua hot spring. The other concentration of trace elements are generally low and similar across hot springs. Given the abundance of trace elements, the hot springs could possibly cure certain diseases, such as psoriasis and eczema. The Batu 16, Sg. Serai and Sg Lalang hot springs have the potential to be developed as important sites for health geotourism industries due to the high trace elements concentration. Thus, this study may serve as a basis for further investigations on this aspect.
\end{abstract}

Keywords: Hot spring; Hulu Langat; mineral; potential health benefit

ABSTRAK

Geopelancongan ialah satu usaha dalam bidang geologi yang menyumbang kepada salah satu daripada 17 matlamat Pembangunan Mampan (SDGS). Salah satu bidang utama dalam geologi yang boleh menyumbang kepada aktiviti geopelancongan ialah penerokaan mata air panas. Oleh itu, kajian ini mengenal pasti mata air panas di Hulu Langat, Selangor dan potensinya terhadap manfaat kesihatan, yang berpotensi dijadikan kawasan geopelancongan. Mata air panas yang dikenali ramai ini adalah Batu 16, Dusun Tua, Institut Kemahiran Belia Negara (IKBN), Sg. Serai, dan Sg. Lalang. Walau pun terkenal dalam kalangan pelancong, potensinya terhadap manfaat kesihatan masih kurang jelas. Oleh itu, pencirian fiziko-kimia dan potensi manfaat kesihatan bagi mata air panas tersebut yang ditunjukkan oleh kelimpahan unsur surih di setiap lokasi akan ditentukan dalam kajian ini. Suhu $\left({ }^{\circ} \mathrm{C}\right)$, kekonduksian elektrik ( $\mu$ s/cm), jumlah pepejal terlarut ( $\mathrm{mg} / \mathrm{L})$, kemasinan (ppt), oksigen terlarut $(\mathrm{mg} / \mathrm{L})$ dan nilai $\mathrm{pH}$ mata air panas diukur secara insitu, dan kepekatan unsur kimia ( $\mathrm{Si}, \mathrm{Li}, \mathrm{Fe}, \mathrm{Pb}, \mathrm{Mn}$, Ni, Se, $\mathrm{Ag}, \mathrm{Na}, \mathrm{Zn}, \mathrm{K}, \mathrm{Mg}, \mathrm{Ca}, \mathrm{Al}, \mathrm{As}, \mathrm{Ba}, \mathrm{Cd}, \mathrm{Cr}$ and $\mathrm{Cu}$ ) di dalam mata air panas ditentukan melalui kajian makmal. Berdasarkan hasil pengukuran in-situ, mata air panas dikelaskan berdasarkan nilai $\mathrm{pH}$ dan suhunya. Julat pH adalah 6.83-8.71 menunjukkan mata air panas ini adalah neutral ke alkali lemah. Suhu paling rendah $\left(40.47^{\circ} \mathrm{C}\right)$ telah direkodkan di mata air panas Dusun Tua, manakala suhu tertinggi (70.41$74.03^{\circ} \mathrm{C}$ ) telah didapati di mata air IKBN. Kepekatan $\mathrm{Si}, \mathrm{Li}, \mathrm{Na}, \mathrm{K}$, As dan Cu yang tinggi ditemukan di mata air panas Batu 16. Kepekatan Fe dan Ca didapati lebih tinggi di Sg Serai dan Sg Lalang, manakala kepekatan K tertinggi ditemukan di mata air Dusun Tua. Kepekatan unsur surih dalam mata air panas di lokasi lain secara umumnya rendah dan hampir sama. Berdasarkan kelimpahan unsur surih, Unsur kimia mata air panas ini mungkin juga dapat menyembuhkan penyakitpenyakit tertentu, seperti psoriasis dan ekzema. Mata air panas Batu 16, Sg. Serai dan Sg Lalang mempunyai potensi untuk dibangunkan sebagai tapak penting industri geopelancongan kesihatan. Oleh itu, kajian ini boleh dijadikan asas kepada kajian lanjutan dalam aspek yang sama.

Kata kunci: Hulu Langat; mata air panas; mineral; potensi manfaat untuk kesihatan 


\section{INTRODUCTION}

Geotourism is defined as tourism activities that revolve around locations that are known for its geological attraction (Newsome \& Dowling 2006). Geotourism activities have been recognised as one of the key areas in geology that may contribute to the sustainable development goals as outlined in Gill (2017). As pointed by Gill, geotourism which encourages education as part of its program will indirectly help to conserve natural resources for future generation. Due to its importance, geotourism has also been used as a policy instrument (Chakrabarty \& Mandal 2018). Geothermal or hot spring has been part of geotourism and other types of tourism such as eco- and adventure tourisms (Erfurt-Cooper 2010). In general, hot thermal springs are sites where warm water emerges to the earth surface on a regular basis and where the ambient temperature is significantly different from the ground temperature (Dash et al. 2013; Sherpa et al. 2013). White and Brannock (1950) categorised thermal springs into three types: nonvolcanic, intermediate and volcanic. The heat source for non-volcanic thermal spring is not always related to volcanism. For intermediate thermal springs, the excess heat is caused by unusually high geothermal gradients resulting from volcanism, but the source of water is purely meteoric. Volcanic-related thermal spring is characterised by the presence of excess heat, mineral content, and water that partly originated from a volcanic source.

Geological material and processes are known for their medicinal benefits, in particular, hot springs contain beneficial trace elements that may cure skin diseases and joint pain (Finkelman 2006). Common soluble minerals such as calcium $\left(\mathrm{Ca}^{2+}\right)$, bicarbonate $\left(\mathrm{CO}_{3} \mathrm{H}^{-}\right)$, silicates, iron compounds, sodium, magnesium, sulphur, metal and selenium are present in hot springs as a result of water interaction with geological materials (Seite 2013). Water containing these salts is believed to have therapeutic effects for various skin diseases.

This study explores the physico-chemical properties of five Hulu Langat hot springs in Selangor, namely, Batu 16, Dusun Tua, National Youth Training Institute (IKBN), $\mathrm{Sg}$. Serai and Sg. Lalang. These properties could signify the scientific significance of these sites which is an important element in geotourism development (Kuleta 2018). This study also includes the potential health benefits of trace elements from these hot springs. To date, the potential health benefits of immersing oneself in these thermal pools have received little attention. Only a study by Hamzah et al. (2013) explored the balneotherapeutic potential of these hot springs. We would like to expand this research by measuring trace elements from these hot springs and classifying the type of hot springs based on their physical properties based on comparison with other hot springs worldwide.

\section{GEOLOGY OF THE STUDY AREA}

Kamal Roslan (1999) indicate Hulu Langat granite as Devonian or Silurian age. Based on the geological map published by the Mineral and Geoscience Department of Malaysia (1985), the study area is covered with acid intrusive and volcanic rocks, metamorphic rocks such as phyllite, schist and slate, and limestone. These rock types and their distribution are presented in Figure 1.

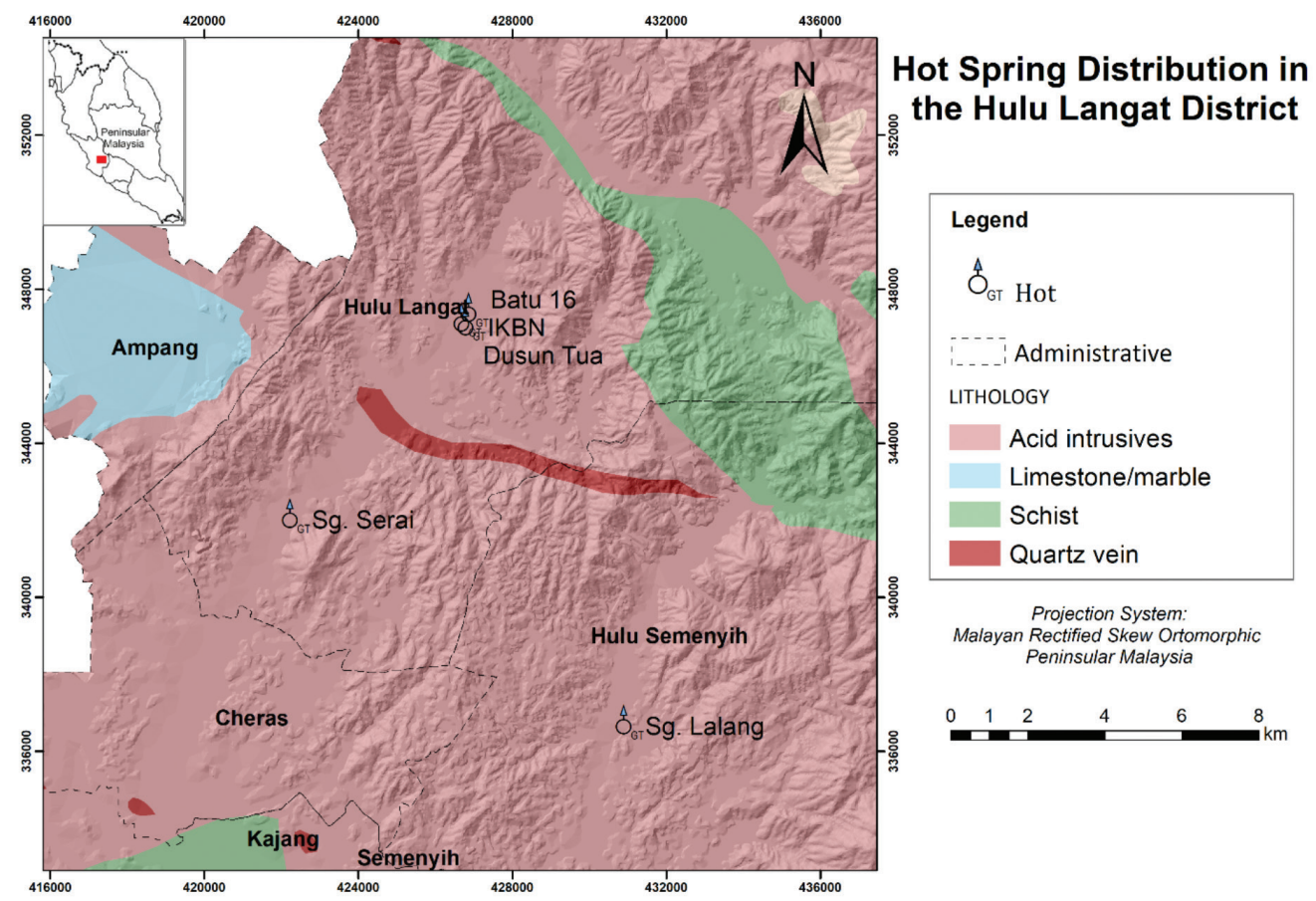

FIGURE 1. Location and distribution of hot springs in the study area 


\section{HOT SPRING CLASSIFICATION}

Bryan (1919) classified spring water into non-thermal and thermal classes. Non-thermal spring refers to measured temperature that is similar to the mean annual temperature of the surrounding region. By contrast, thermal spring has temperatures approximately $20^{\circ} \mathrm{C}$ to $25^{\circ} \mathrm{C}$ above the mean temperature of the region. However, 'warmness' has different definitions in different climatic conditions. Hence, the exact temperature for thermal and non-thermal springs remains controversial at the moment (Olivier et al. 2008). Other classification systems are based on temperature, pH value and chemical compounds. Matz et al. (2003) classified hot springs into four types based on their temperature: Cold $\left(<20^{\circ} \mathrm{C}\right)$, hypothermal $\left(20-30^{\circ} \mathrm{C}\right)$, thermal $\left(30-40^{\circ} \mathrm{C}\right)$ and hyperthermal $\left(>40^{\circ} \mathrm{C}\right)$. Meanwhile, Subtavewung et al. (2005) proposed six classes of hot springs: Strong acid spring $(\mathrm{pH}<2)$, acid spring $(2 \leq \mathrm{pH}<$ $4)$, weak acid spring $(4 \leq \mathrm{pH}<6)$, neutral spring $(6 \leq \mathrm{pH}$ $<7.5)$, weak alkaline spring $(7.5 \leq \mathrm{pH}<9)$ and alkaline spring $(\mathrm{pH} \geq 9)$.

Waters in hot spring can also be classified based on their chemical compounds. Reyes et al. (2015) divided hot springs into five classes based on the dominance of anions or cations: ferruginous waters $\left(\mathrm{Fe}^{2+}\right)$ or ferric $\left(\mathrm{Fe}^{3+}\right)$, chlorinated water $\left(\mathrm{Cl}^{-}\right)$, sulphurous waters $\left(\mathrm{S}^{2-}\right)$, sulphated waters $\left(\mathrm{S}_{4}{ }^{2-}\right)$ and bicarbonated water $\left(\mathrm{HCO}_{3}^{-}\right)$. Similarly, Markiey et al. (2005) categorised hot springs into six classes: Sodium carbonate, sulphur, ferrous, sodium hydrogen carbonate, mud and salt or hydrogen sulphide.

\section{MEDICINAL PROPERTIES OF HOT SPRINGS}

Mineral water from hot springs has been reportedly cure diseases in Eastern Asia (Tantayanaboon \& Penkar 2016). In Europe and Japan, licensed medical practitioners actually prescribe mineral containing waters as part of preventive medicines (Finkelman 2006). To experience the health benefits of hot springs, one must immerse herself/himself in the water (Matz et al. 2003). According to Matz et al. (2003), taking a bath in mineral water is safe and healthy to humans. According to them, certain diseases, including psoriasis, atopic dermatitis, alopecia areata, contact dermatitis, dyshidrotic dermatitis, eczema, granuloma annulare, ichthyosis vulgaris, lichen planus, lichen sclerosus and atrophicus, and mycosis fungoides, could be cured with balneotherapy.

Several studies demonstrated the effectiveness of mineral water in treating diseases. For example, SahinOnat et al. (2015) reported that balneotherapy improved knee osteoarthritis. In addition, Golusin et al. (2014) found that balneotherapy treated patients suffering from psoriasis and attributed this effect to the in-vitro, antiinflammatory, anti-bacterial and anti-fungal properties of mineralised water. Ablin et al. (2013) reviewed studies that used mineralised water to treat fibromyalgia syndrome and rheumatic disorders through spa treatment.

In Japan, hot springs with temperatures above $25^{\circ} \mathrm{C}$ are considered therapeutic. In Germany, hot thermal springs with a temperature of $20^{\circ} \mathrm{C}$ have medicinal benefits (Tantayanaboon \& Penkar 2016). Javed et al. (2009) reported that European balneotherapists treat atherosclerosis with warm water around $32-37^{\circ} \mathrm{C}$. Rosca (2003) implied that thermal water with temperatures of $36-37^{\circ} \mathrm{C}$ has health benefits, such as increase heart rate and cardiac flow, lower blood pressure, cure muscle spasms, control soft tissue pain, treat osteoarticular infection and rebalance the neurovegetative system. However, certain health conditions restrict a person from undertaking bathing activities in a hot spring because different individuals may have different levels of tolerance to temperature (Javed et al. 2009). Apart from tolerance to temperature, skin irritation due to high salt concentrations may also be experienced (Matz et al. 2003). The United Kingdom Home Care Association suggested that the safe temperature of water for bathing must not exceed $44^{\circ} \mathrm{C}$ (UKHCA 2016). The guidelines explained that higher temperature may pose scalding and burning risks to vulnerable people, such as children, the elderly, people with reduced mobility and people with reduced mental capacity.

\section{METHODS}

In situ parameters were measured by using the YSI Multi Probe System model 556 MPS. The probe was rinsed by using distilled water each time before sampling. The following parameters were recorded by the probe: Temperature $\left({ }^{\circ} \mathrm{C}\right)$, conductivity $(\mu \mathrm{s} / \mathrm{cm})$, total dissolved solid (TDS) (mg/L), salinity (Sal, ppt), dissolved oxygen (DO, $\mathrm{mg} / \mathrm{L}$ ) and $\mathrm{pH}$ values. The probe was placed in the hot spring water source for the in-situ measurements. The coordinate for each sampling site was also taken using a Garmin Monterra handheld GPS.

Water samples were collected for trace elements analysis (chemical compounds) in the laboratory. The water samples were placed in $500 \mathrm{~mL}$ bottles washed with $10 \%$ HCL acid (diluted) and later washed with the sample's water. These bottles containing water samples were later transferred into a cooling box and stored in a refrigerator at $20^{\circ} \mathrm{C}$. ICP-MS was used to determine the concentration of trace elements within each sample with an accuracy of up to ppt.

\section{HOT SPRING SITES}

Five hot spring sites have been identified in two constituencies, Hulu Langat and Semenyih (Figure 1), namely the Batu 16, Dusun Tua, IKBN of Hulu Langat District, Sg. Serai and Sg. Lalang hot springs. Short descriptions for each hot spring are given as follows:

\section{BATU 16}

This Batu 16 hot spring site is privately owned and located at Batu 16 in Hulu Langat District. The site is open to the public and is well maintained. Hot thermal water is transferred to a large man-made wash basin. Facilities such as toilet and prayer house are also provided. Areas for 
bathing activities are given separately for men and women. Entrance is free, but donations are welcomed. Figure 2 shows the Dusun Tua hot spring site.

\section{IKBN}

This IKBN hot spring site is located approximately $2 \mathrm{~km}$ from the Batu 16 hot spring. It is a government training institute for the youth, and permission is needed to enter the site. Four hot springs are located at this site alone with one of the spring water is flowing into the Sungai Langat outside the institute compound. Figure 3 shows the hot spring pools observed in this area.

\section{DUSUN TUA}

The Dusun Tua hot spring site refers to a small concrete pool outside the IKBN compound for public. Visitors are free to use this pool (Figure 4).

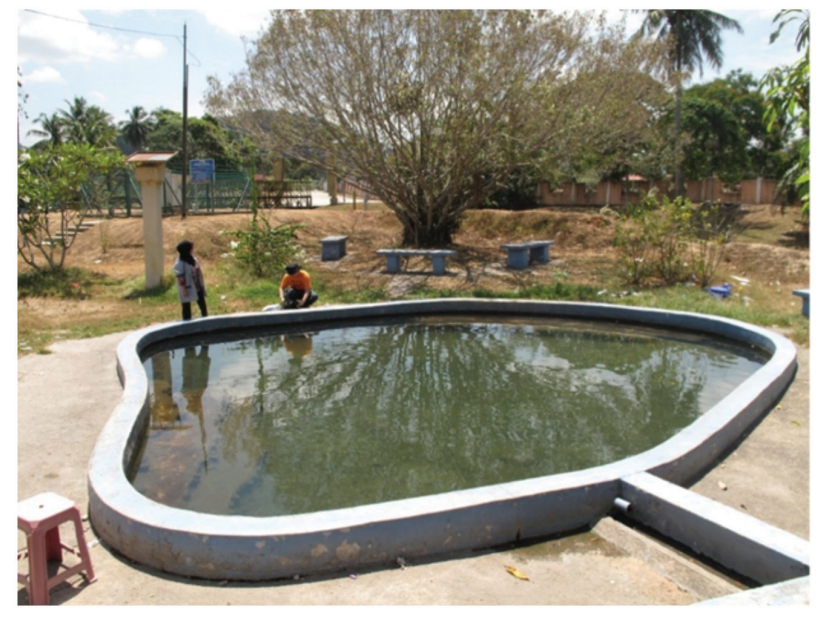

FIGURE 4. Hot thermal pool for public use located outside IKBN (Dusun Tua hot spring)

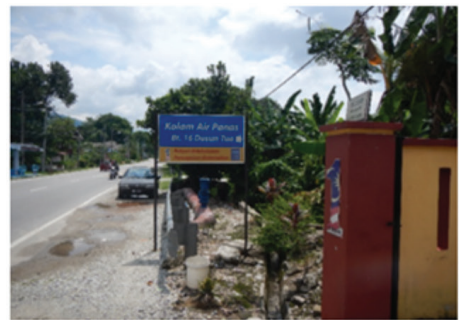

(a)

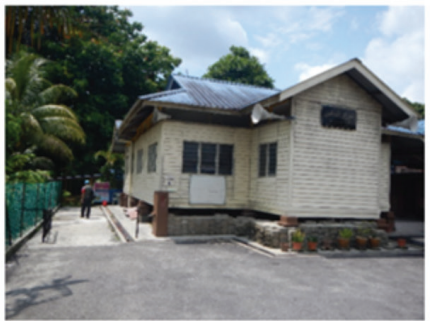

(b)

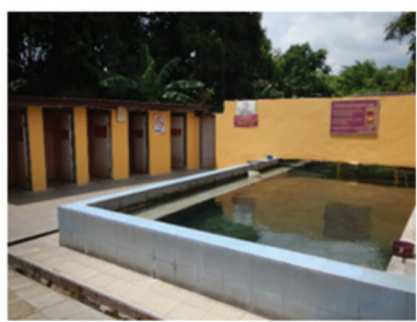

(c)

FIGURE 2. Location of the hot spring sites can be easily recognised based on (a) the sign post by the road side,

(b) site entrance, and (c) large man-made concrete pool filled with hot water

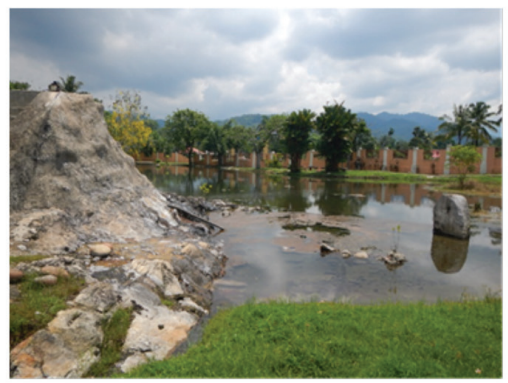

(a)

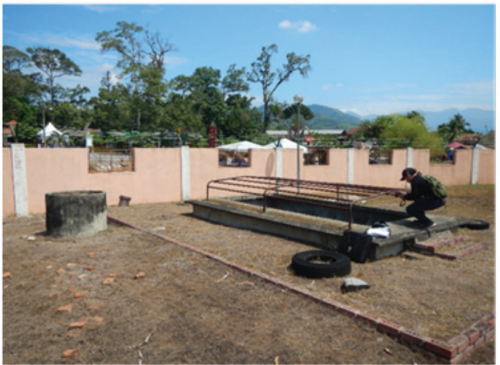

(c)

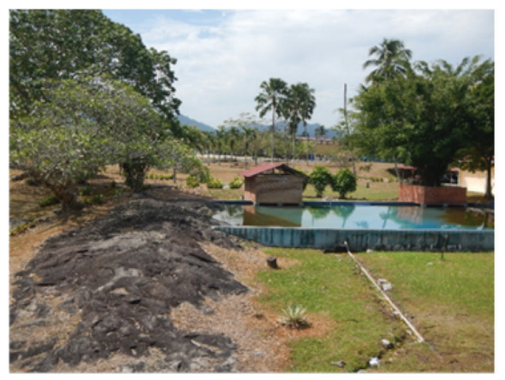

(b)

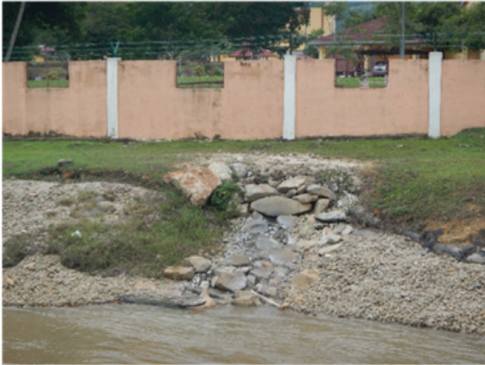

(d)

FIGURE 3. The IKBN hot spring. (a) Close up of the man-made structure containing hot thermal water,

(b) concreted pool for the institute usage, (c) another pool containing hot water discharge from the ground and (d) discharge of hot thermal water into the Langat River located outside the institute 


\section{SG. SERAI (SS)}

Although this site is privately owned (Figure 5), the Sg. Serai hot spring site is open to the public and a RM2 fee is charged to those who wish to bath. Basic facilities such as water buckets, chairs, toilets and a parking area are provided for the public. Two spring water sources are found in this site, the main large pool (Figure 5(a)), and the small fissures on the ground, surrounded with concrete well (Figure 5(b)).

\section{SG. LALANG}

This Sg. Lalang site is also open to public and is privately owned. The owner provides few basic facilities, such as toilet, large parking area and a small shop for snacking. Concrete well is built around the thermal pool for the visitors to sit and enjoy the hot water (Figure 6(a)). A smaller concrete hot spring well is also built at the rear of the main pool (Figure 6(b)).

\section{SAMPLING LOCATION}

The water sampling locations for each hot spring are given in Table 1. Nine sampling stations have been selected in the study area. Three stations are are selected in IKBN (IKBN1, IKBN4, IKBN5, two in each Sg. Serai (SS1 \& SS2) and Sg. Lalang (SL1 \& SL2) and one each in Batu 16 and Dusun Tua hot springs.

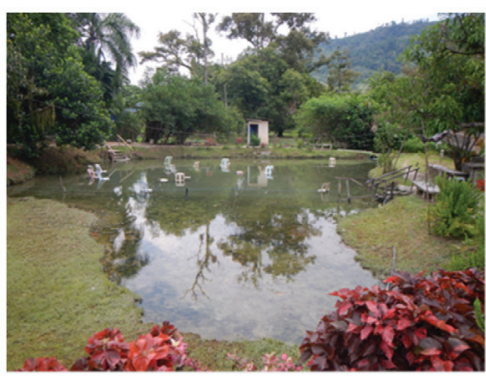

(a)

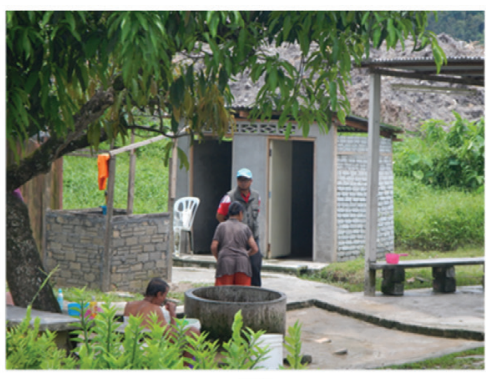

(b)

FIGURE 5. A hot spring pool at Sg. Serai area (a) Hot spring is open for public, (b) small concreted well containing hot spring water

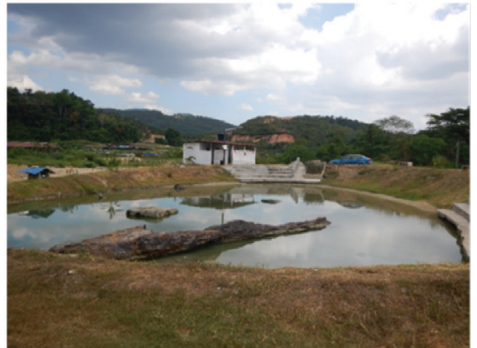

(a)

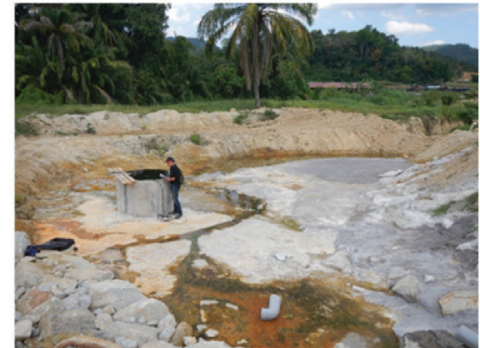

(b)

FIGURE 6. Location of hot spring pool at Sg. Lalang, Semenyih (a) The pool is open to visitors, (b) Concreted hot spring well at the rear of the main hot spring pool

TABLE 1. The Hulu Langat hot springs sampling locations and their usage

\begin{tabular}{lcccc}
\hline Hot spring & Station & $\mathrm{X}$ & $\mathrm{Y}$ & Current use \\
\hline Batu 16 & Dusun Tua & $101.8377^{\circ}$ & $3.139306^{\circ}$ & Recreation \\
IKBN & IKBN 1 & $101.8366^{\circ}$ & $3.136139^{\circ}$ & \\
& IKBN 4 & $101.8356^{\circ}$ & $3.136694^{\circ}$ & Private use \\
& IKBN 5 & $101.8357^{\circ}$ & $3.136583^{\circ}$ & \\
Dusun Tua & Dusun Tua & $101.836^{\circ}$ & $3.137083^{\circ}$ & Recreation \\
Sg. Serai & SS1 & $101.7960^{\circ}$ & $3.090917^{\circ}$ & Recreation \\
& SS2 & $101.7960^{\circ}$ & $3.090889^{\circ}$ & \\
Sg. Lalang & SL1 & $101.8739^{\circ}$ & $3.042556^{\circ}$ & Recreation \\
& SL2 & $101.8741^{\circ}$ & $3.042583^{\circ}$ & \\
\hline
\end{tabular}




\section{PHYSICOCHEMICAL PROPERTIES OF THE HULU LANGAT HOT SPRING}

The findings on the Hulu Langat hot springs are divided into two parts. Firstly, the field properties of the Hulu Langat hot springs are explained. Later, the chemical compounds derived from lab tests are discussed.

\section{FIELD PROPERTIES}

A fieldwork has been conducted to acquire the in-situ properties, including $\mathrm{pH}$ values, temperature (Temp), conductivity, TDS, salinity and DO of the selected hot spring stations (Table 2). Values of each parameter as found in the literature were also included in Table 2 for discussion purposes.

\section{TEMPERATURE}

As shown in Table 2, the highest temperatures were measured in the IKBN1, IKBN4 and IKBN5 sampling stations. The measurement was conducted directly at the emerging water source. Although the Dusun Tua hot spring is located near the IKBN hot spring, the recorded temperature is lower. The water that was channelled through a PVC tube from the Batu 16 hot spring also recorded a high temperature of $60.46^{\circ} \mathrm{C}$. Batu 16 hot spring water source was not visible during the assessment. The variation in temperatures may indicate different hot spring origin or the water was influenced by various conditions along its path to the surface. On the basis of the water temperature across the hot springs in Hulu Langat, the hot springs can be classified as hyperthermal spring (Table 3 ).

\section{$\mathrm{pH}$}

Among the stations studied, five stations (Batu 16, IKBN1, IKBN4, IKBN5 and Dusun Tua) recorded similar $\mathrm{pH}$ values of around 8 (Table 3 ). The $\mathrm{pH}$ values at the four other stations (SS1, SS2, SL1 and SL2) were lower ( $\mathrm{pH}$ 7.277.44 ), with the lowest recorded at SS2 hot spring, which is 6.83 (Table 3 ). The hot spring can be classified as neutral to weak alkaline in accordance with the criteria by Subtavewung et al. (2005).

\section{CONDUCTIVITY, TDS AND SALINITY}

Conductivity in water is referred to the ability of water to conduct an electric current which is determined by the presence of ionic content of dissolved solid concentration (EPA 2001). TDS is defined as cations or anions in water from all organic and inorganic substances that are finer or much less than 2 micron (Raisbeck et al. 2008). These cations and anions are mostly carbonate, bicarbonate, chloride, fluoride, sulphate, phosphate, nitrate, calcium, magnesium, sodium and potassium. Raisbeck et al. (2008) suggested that the chemical composition of water with TDS values exceeding $500 \mathrm{mg} / \mathrm{L}$ must be assessed. The Department of Sustainability, Environment, Water, Population and Communities of Australia defined salinity as a measure of salts in water that are highly soluble and can be transported on the surface or groundwater with the movement of water (Department of Sustainability, Environment, Water, Population and Communities 2012).

As shown in Table 2, the hot springs in stations IKBN1, IKBN4, IKBN5, Dusun Tua, SS1, SS2 and SL2 have higher conductivity than those in other stations (Batu 16 and SL1). The highest conductivity was recorded in SL2 and the lowest in Batu 16. Similar values of TDS were recorded for all stations, except for Batu 16 and SL1, which have lower TDS compare to that of other stations. The highest recorded TDS was in station SL2 and the lowest in Batu 16 (91 mg/L). In terms of salinity, similar values were observed in stations IKBN1, IKBN4, IKBN5, Dusun Tua, Ss1, Ss2 and SL2. Both the Dusun Tua and SL1 stations recorded a lower salinity values of 0.06 and $0.08 \mathrm{ppt}$, respectively.

TABLE 2. The in-situ parameters (temperature, conductivity, TDS, salinity, DO and pH values) for Hulu Langat hot springs as compared to previous literatures

\begin{tabular}{|c|c|c|c|c|c|c|c|}
\hline Site & Sampling station & Temp $\left({ }^{\circ} \mathrm{C}\right)$ & Cond $(\mathrm{ms} / \mathrm{cm})$ & $\mathrm{TDS}(\mathrm{mg} / \mathrm{L})$ & Sal (ppt) & $\mathrm{DO}(\mathrm{mg} / \mathrm{L})$ & $\mathrm{pH}$ \\
\hline \multirow[t]{2}{*}{ Batu 16} & Batu 16 & 60.46 & 0.235 & 91 & 0.06 & 0.08 & 8.44 \\
\hline & Hamzah et al. (2013) & 67.9 & 0.369 & 228 & 0.17 & 2.64 & 7.86 \\
\hline \multirow[t]{3}{*}{ IKBN } & IKBN 1 & 70.41 & 0.509 & 177 & 0.12 & 0.09 & 8.54 \\
\hline & IKBN 4 & 73.94 & 0.544 & 183 & 0.12 & 0 & 8.27 \\
\hline & IKBN 5 & 74.03 & 0.545 & 183 & 0.12 & 0.39 & 8.42 \\
\hline \multirow[t]{2}{*}{ Dusun Tua } & Dusun Tua & 40.47 & 0.375 & 188 & 0.13 & 0.44 & 8.71 \\
\hline & Hamzah et al. (2013) & 36.1 & 0.595 & 373 & 0.28 & 2.99 & 7.34 \\
\hline \multirow[t]{4}{*}{ Sg. Serai } & SS1 & 43.53 & 0.372 & 179 & 0.13 & 1.33 & 7.27 \\
\hline & SS2 & 46.07 & 0.386 & 179 & 0.13 & 1.29 & 6.83 \\
\hline & Baioumy et al. (2015) & 45 & - & - & - & - & 7.5 \\
\hline & Hamzah et al. (2013) & 45.4 & 0.56 & 343 & 0.25 & 2.8 & 7.73 \\
\hline \multirow[t]{4}{*}{ Sg. Lalang } & SL1 & 51.8 & 0.261 & 112 & 0.08 & 0.12 & 7.44 \\
\hline & SL2 & 51.52 & 0.449 & 194 & 0.13 & 0.61 & 7.32 \\
\hline & Hamzah et al. (2013) & 36.7 & 0.559 & 3.64 & 0.27 & 4.91 & 7.45 \\
\hline & Baioumy et al. (2015) & 41 & - & - & - & - & 7.5 \\
\hline
\end{tabular}

Station: IKBN = Institut Kemahiran Belia Negara, SS = Sungai Serai, SL = Sungai Lalang, TDS = Total Dissolved Solid, DO = Dissolved Oxygen 
TABLE 3. The classification of Hulu Langat hot springs based on temperature and $\mathrm{pH}$ values

\begin{tabular}{lcccc}
\hline \multirow{2}{*}{ Station } & \multicolumn{2}{c}{ Temp. based } & \multicolumn{2}{c}{$\mathrm{pH}$ based } \\
\cline { 2 - 5 } & Temp. $\left({ }^{\circ} \mathrm{C}\right)$ & Classification & $\mathrm{pH}$ & Classification \\
\hline Dusun Tua & 60.46 & Hyper thermal & 8.44 & Weak alkaline spring \\
IKBN1 & 70.41 & Hyper thermal & 8.54 & Weak alkaline spring \\
IKBN4 & 73.94 & Hyper thermal & 8.27 & Weak alkaline spring \\
IKBN5 & 74.03 & Hyper thermal & 8.42 & Weak alkaline spring \\
Batu 16 & 40.47 & Hyper thermal & 8.71 & Weak alkaline spring \\
SS1 & 43.53 & Hyper thermal & 7.27 & Neutral spring \\
SS2 & 46.07 & Hyper thermal & 6.83 & Neutral spring \\
SL1 & 51.8 & Hyper thermal & 7.44 & Neutral spring \\
SL2 & 51.52 & Hyper thermal & 7.32 & Neutral spring \\
\hline
\end{tabular}

Compared to those of other studies conducted in the same area, the current results are consistent for the recorded $\mathrm{pH}$ values and temperatures across hot springs. However, there is exception for Sg. Lalang hot spring, where the measured temperature was higher than that of recorded temperatures in previous literatures. According to the $\mathrm{pH}$ values in previous studies, the hot springs are classified as neutral to weak alkaline, which is consistent with current finding.

In terms of temperature, Hamzah et al. (2013) reported that the Dusun Tua and Sg. Lalang hot springs have temperatures of $36.1^{\circ} \mathrm{C}$ and $36.7^{\circ} \mathrm{C}$, respectively. Therefore, both hot springs are classified as thermal, which is not in agreement with the current study (i.e. hyperthermal). The conductivity, TDS, salinity and DO recorded in the present study are also inconsistent with those in the literatures. The inconsistency might be due to various environment and weather conditions during data collection.

\section{CHEMICAL CONSTITUENTS}

The concentrations of trace elements ( $\mathrm{Si}, \mathrm{Li}, \mathrm{Fe}, \mathrm{Pb}, \mathrm{Mn}, \mathrm{Ni}$, $\mathrm{Se}, \mathrm{Ag}, \mathrm{a}, \mathrm{Zn}, \mathrm{k}, \mathrm{Mg}, \mathrm{Ca}, \mathrm{Al}, \mathrm{As}, \mathrm{Ba}, \mathrm{Cd}, \mathrm{Cr}$ and $\mathrm{Cu}$ ) in five hot springs stations are presented in Table 4. Sulphur was not included in the analysis due to the unavailability of sulphur standard during the analysis, Besides, restriction to enter the site for sample recollection, and the strict duration to retain the old samples for accurate analysis. Although sulphur is an important element in a hot spring, it is not the only contributing element that benefits health. Therefore, in this study, other elements are used for health benefit indicators.

As indicated in Table 4, the highest concentrations of $\mathrm{Si}, \mathrm{Li}, \mathrm{Na}, \mathrm{K}, \mathrm{As}$ and $\mathrm{Cu}$ were recorded in Batu 16 hot spring water. Although Batu 16 has the highest numbers and concentrations of many trace elements, other hot springs are also have high concentrations of certain elements that are less abundant in Batu 16. For example, $\mathrm{Fe}$ and $\mathrm{Ca}$ are abundant in the Sg. Serai (SS1 \& SS2) and Sg. Lalang hot springs, $\mathrm{Mn}$ and $\mathrm{Ni}$ are high in $\mathrm{Sg}$. Lalang hot spring, and $\mathrm{K}$

TABLE 4. The concentration of trace elements ( $\mathrm{mg} / \mathrm{L})$ studied in Hulu Langat hot springs

\begin{tabular}{cccccccccc}
\hline Trace & Batu 16 & IKBN1 & IKBN4 & IKBN5 & Dusun Tua & SS1 & SS2 & SL1 & SL2 \\
\hline $\mathrm{Si}$ & 45.3126 & 42.1943 & 38.0432 & 43.5083 & 42.1801 & 31.1663 & 31.3569 & 28.1172 & 27.9635 \\
$\mathrm{Li}$ & 0.1071 & 0.0519 & 0.0808 & 0.0945 & 0.1040 & 0.0483 & 0.0613 & 0.0840 & 0.0487 \\
$\mathrm{Fe}$ & 0.0163 & 0.0113 & 0.0117 & 0.0077 & 0.0041 & 0.0373 & 0.0399 & 0.0567 & 0.0574 \\
$\mathrm{~Pb}$ & 0.0001 & 0.0000 & 0.0000 & 0.0000 & 0.0000 & 0.0003 & 0.0000 & 0.0002 & 0.0001 \\
$\mathrm{Mn}$ & 0.0026 & 0.0025 & 0.0012 & 0.0008 & 0.0016 & 0.0021 & 0.0006 & 0.0170 & 0.0224 \\
$\mathrm{Ni}$ & 0.0008 & 0.0003 & 0.0004 & 0.0003 & 0.0005 & 0.0009 & 0.0008 & 0.0011 & 0.0009 \\
$\mathrm{Se}$ & 0.0002 & 0.0000 & 0.0002 & 0.0003 & 0.0000 & -0.0004 & -0.0001 & 0.0012 & 0.0001 \\
$\mathrm{Ag}$ & -0.0002 & 0.0006 & -0.0002 & -0.0003 & 0.0000 & -0.0001 & -0.0002 & 0.0000 & -0.0003 \\
$\mathrm{Na}$ & 228.1836 & 32.9887 & 228.1836 & 228.1836 & 228.1836 & 42.3337 & 140.3405 & 137.3887 & 30.1370 \\
$\mathrm{Zn}$ & 0.0158 & 0.0113 & 0.0109 & 0.0081 & 0.0028 & 0.0079 & 0.0051 & 0.0045 & 0.0092 \\
$\mathrm{~K}$ & 3.3885 & 1.4522 & 2.5206 & 2.5425 & 3.5132 & 1.7088 & 2.0821 & 2.4427 & 1.6409 \\
$\mathrm{Mg}$ & 0.0374 & 0.0119 & 0.0143 & 0.0200 & 0.0124 & 0.0304 & 0.0328 & 0.0588 & 0.0425 \\
$\mathrm{Ca}$ & 0.4572 & 0.3359 & 0.3365 & 0.3514 & 0.3696 & 1.3909 & 1.3841 & 1.3833 & 1.3735 \\
$\mathrm{Al}$ & 0.0472 & 0.0266 & 0.0307 & 0.0359 & 0.0187 & 0.0060 & 0.0064 & 0.0081 & 0.0055 \\
$\mathrm{As}$ & 0.0192 & 0.0106 & 0.0167 & 0.0173 & 0.0186 & 0.0002 & 0.0003 & 0.0014 & 0.0004 \\
$\mathrm{Ba}$ & 0.0015 & 0.0006 & 0.0012 & 0.0007 & 0.0005 & 0.0016 & 0.0025 & 0.0017 & 0.0013 \\
$\mathrm{Cd}$ & 0.0000 & 0.0000 & 0.0000 & 0.0000 & 0.0000 & 0.0000 & 0.0000 & 0.0001 & 0.0000 \\
$\mathrm{Cr}$ & 0.0026 & 0.0018 & 0.0021 & 0.0025 & 0.0053 & 0.0019 & 0.0017 & 0.0045 & 0.0023 \\
$\mathrm{Cu}$ & 0.0017 & 0.0003 & 0.0009 & 0.0005 & 0.0006 & 0.0009 & 0.0006 & 0.0009 & 0.0004 \\
\hline
\end{tabular}


and $\mathrm{Cr}$ are high in the Dusun Tua hot spring. The $\mathrm{K}$ content in Dusun Tua hot spring is slightly higher than that in Batu 16. The Si concentration is consistent in Batu 16, IKBN and Dusun Tua hot springs, whereas the $\mathrm{Na}$ concentration in Batu 16, IKBN and Dusun Tua hot springs are similar.

In comparison to other studies (Table 5), some of the trace elements concentration in a few stations are not in agreement with the previous studies. In reference to the study by Auna (2014), the concentration of trace elements in Sg. Serai (SS1) hot spring is notably different from the current study, whereas $\mathrm{Fe}$ and $\mathrm{K}$ show only slight differences. Baioumy et al. (2015) presented similar results to the current study for the $\mathrm{Na}$ and $\mathrm{K}$ concentrations of the $\mathrm{Sg}$. Serai hot spring (SS1). However, the concentrations of other trace elements (Fe, $\mathrm{Mg}$ and $\mathrm{Ca}$ ) are inconsistent with current findings. Atiqah et al. (2017) also presented different results for all trace elements, except for $\mathrm{K}$. On the basis of the five elements (Fe, $\mathrm{Na}, \mathrm{K}, \mathrm{Mg}$ and $\mathrm{Ca}$ ) presented by Baioumy et al. (2015), it is found that only the concentration of $\mathrm{K}$ is similar to the current result.

TABLE 5. The trace elements content in Hulu Langat hot springs as compare to previous literatures

\begin{tabular}{|c|c|c|c|c|c|c|c|c|c|}
\hline Elem & $\begin{array}{c}\text { SS1 } \\
\text { (pool) }\end{array}$ & $\begin{array}{c}\text { SS2 } \\
\text { (well) }\end{array}$ & $\begin{array}{c}\text { Anua } \\
(2014)\end{array}$ & $\begin{array}{l}\text { Atiqah et al. } \\
(2017) \text { (pool) }\end{array}$ & $\begin{array}{l}\text { Atiqah et al. } \\
\text { (2017) (well) }\end{array}$ & $\begin{array}{l}\text { Baioumy } \\
\text { et al. (2015) }\end{array}$ & $\begin{array}{c}\text { SL1 } \\
(\text { pool })\end{array}$ & $\begin{array}{c}\text { SL2 } \\
\text { (well) }\end{array}$ & $\begin{array}{c}\text { Baioumy et al. } \\
\text { (2015) }\end{array}$ \\
\hline $\mathrm{Si}$ & 31.1663 & 31.3569 & - & 68.86 & 65.59 & - & 28.1172 & 27.9635 & - \\
\hline $\mathrm{Li}$ & 0.0483 & 0.0613 & 0.073968 & - & - & - & 0.084 & 0.0487 & - \\
\hline $\mathrm{Fe}$ & 0.0373 & 0.0399 & 0.056534 & 0.165 & 0.292 & 0.2 & 0.0567 & 0.0574 & $<0.1$ \\
\hline $\mathrm{Pb}$ & 0.0003 & 0 & 0.000029 & -0.013 & -0.019 & - & 0.0002 & 0.0001 & - \\
\hline $\mathrm{Mn}$ & 0.0021 & 0.0006 & 0.000173 & 0.011 & 0.025 & - & 0.017 & 0.0224 & - \\
\hline $\mathrm{Ni}$ & 0.0009 & 0.0008 & 0.00053 & 0 & 0.002 & - & 0.0011 & 0.0009 & - \\
\hline $\mathrm{Se}$ & -0.0004 & -0.0001 & 0.000715 & 0.01 & -0.004 & - & 0.0012 & 0.0001 & - \\
\hline $\mathrm{Ag}$ & -0.0001 & -0.0002 & 0.000029 & 0.013 & 0.01 & - & 0 & -0.0003 & - \\
\hline $\mathrm{Na}$ & 42.3337 & 140.3405 & 238.612687 & 51.24 & 49.62 & 40.8 & 137.3887 & 30.137 & 44.8 \\
\hline $\mathrm{Zn}$ & 0.0079 & 0.0051 & -0.00023 & 0.027 & 0.048 & - & 0.0045 & 0.0092 & - \\
\hline $\mathrm{K}$ & 1.7088 & 2.0821 & 2.366353 & 1.94 & 1.827 & 1.9 & 2.4427 & 1.6409 & 2.8 \\
\hline $\mathrm{Mg}$ & 0.0304 & 0.0328 & 0.02488 & 0.07 & 0.058 & 0.2 & 0.0588 & 0.0425 & 0.1 \\
\hline $\mathrm{Ca}$ & 1.3909 & 1.3841 & 4.904085 & 11.47 & 12.57 & 13.5 & 1.3833 & 1.3735 & 15.4 \\
\hline $\mathrm{Al}$ & 0.006 & 0.0064 & 0.0187 & 0.224 & 0.009 & - & 0.0081 & 0.0055 & - \\
\hline As & 0.0002 & 0.0003 & 0.00077 & -0.005 & -0.007 & - & 0.0014 & 0.0004 & - \\
\hline $\mathrm{Ba}$ & 0.0016 & 0.0025 & 0.000955 & - & - & - & 0.0017 & 0.0013 & - \\
\hline $\mathrm{Cd}$ & 0 & 0 & -0.00008 & 0 & -0.001 & - & 0.0001 & 0 & - \\
\hline $\mathrm{Cr}$ & 0.0019 & 0.0017 & 0.00938 & 0 & 0 & - & 0.0045 & 0.0023 & - \\
\hline $\mathrm{Cu}$ & 0.0009 & 0.0006 & 0.001814 & 0.012 & 0.012 & - & 0.0009 & 0.0004 & - \\
\hline
\end{tabular}

(Continued) TABLE 5.

\begin{tabular}{|c|c|c|c|c|c|c|c|c|c|}
\hline Elem & Batu 16 & Anua (2014) & Dusun Tua & Anua (2014) & $\begin{array}{l}\text { Mohd Hasni } \\
\text { et al. (2017) }\end{array}$ & IKBN1 & IKBN4 & IKBN5 & Anua (2014) \\
\hline $\mathrm{Si}$ & 45.3126 & - & 42.1801 & - & - & 42.1943 & 38.0432 & 43.5083 & - \\
\hline $\mathrm{Li}$ & 0.1071 & 0.127072 & 0.104 & 0.130417 & - & 0.0519 & 0.0808 & 0.0945 & 0.120152 \\
\hline $\mathrm{Fe}$ & 0.0163 & 0.0011855 & 0.0041 & 0.038005 & - & 0.0113 & 0.0117 & 0.0077 & 0.010102 \\
\hline $\mathrm{Pb}$ & 0.0001 & -0.000009 & 0 & 0.000108 & 0.0098 & 0.0000 & 0.0000 & 0.0000 & -0.000012 \\
\hline $\mathrm{Mn}$ & 0.0026 & 0.000881 & 0.0016 & 0.01842 & - & 0.0025 & 0.0012 & 0.0008 & 0.006686 \\
\hline $\mathrm{Ni}$ & 0.0008 & 0.0002 & 0.0005 & 0.00054 & - & 0.0003 & 0.0004 & 0.0003 & 0.000217 \\
\hline $\mathrm{Se}$ & 0.0002 & 0.000207 & 0 & 0.000241 & - & 0.0000 & 0.0002 & 0.0003 & 0.000214 \\
\hline $\mathrm{Ag}$ & -0.0002 & 0.000043 & 0 & 0.00004 & - & 0.0006 & -0.0002 & -0.0003 & 0.000124 \\
\hline $\mathrm{Na}$ & 228.1836 & 238.612687 & 228.184 & 238.612687 & - & 32.9887 & 228.1836 & 228.1836 & 238.612687 \\
\hline $\mathrm{Zn}$ & 0.0158 & -0.000175 & 0.0028 & 0.01138 & - & 0.0113 & 0.0109 & 0.0081 & 0.000578 \\
\hline $\mathrm{K}$ & 3.3885 & 2.87418 & 3.5132 & 4.10872 & - & 1.4522 & 2.5206 & 2.5425 & 2.775343 \\
\hline $\mathrm{Mg}$ & 0.0374 & 0.006487 & 0.0124 & 0.037106 & - & 0.0119 & 0.0143 & 0.0200 & 0.004443 \\
\hline $\mathrm{Ca}$ & 0.4572 & 1.214141 & 0.3696 & 1.839325 & - & 0.3359 & 0.3365 & 0.3514 & 1.104204 \\
\hline $\mathrm{Al}$ & 0.0472 & 0.022443 & 0.0187 & 0.07942 & - & 0.0266 & 0.0307 & 0.0359 & 0.02793 \\
\hline As & 0.0192 & 0.020781 & 0.0186 & 0.023587 & - & 0.0106 & 0.0167 & 0.0173 & 0.021342 \\
\hline $\mathrm{Ba}$ & 0.0015 & 0.001107 & 0.0005 & 0.002182 & - & 0.0006 & 0.0012 & 0.0007 & 0.000912 \\
\hline $\mathrm{Cd}$ & 0.0000 & -0.000014 & 0 & -0.000013 & 0.01331 & 0.0000 & 0.0000 & 0.0000 & -0.000009 \\
\hline $\mathrm{Cr}$ & 0.0026 & 0.002747 & 0.0053 & 0.007601 & - & 0.0018 & 0.0021 & 0.0025 & 0.005994 \\
\hline $\mathrm{Cu}$ & 0.0017 & 0.001004 & 0.0006 & 0.03211 & - & 0.0003 & 0.0009 & 0.0005 & 0.000976 \\
\hline
\end{tabular}


At the Batu 16 and Dusun Tua hot springs, the concentrations of $\mathrm{Li}, \mathrm{Na}, \mathrm{K}, \mathrm{Se}, \mathrm{As}$ and $\mathrm{Cr}$ in current study are in agreement with the study conducted by Anua (2014). Compared to the study by Mohd Hasni et al. (2017), the concentrations of $\mathrm{Pb}$ and $\mathrm{Cd}$ are completely different. As for the IKBN hot spring, comparable results with Anua (2014) were observed for Fe, Ni, Se, K, Al and As. As shown in the literature, element concentrations are different across authors (Table 5). Physico-chemical changes in hot springs across the years can result from the different sampling dates, seasons, analysis methods, water physical conditions and anthropogenic activities (Dash et al. 2013; Hamzah et al. 2013; Mohd Hasni et al. 2017; Okpokwasili et al. 2013; Olivier et al. 2008; Prakash et al. 2017; Shahub et al. 2016; Singh et al. 2014; Singh \& Sunayana 2017).

Table 6 compares the trace elements found in several hot springs found in the literature that are believed to have some therapeutic benefits. The Batu 16 hot spring was used in the comparison with the literature because it has the most abundance of trace elements in our study area. As indicated in Table 6, the concentrations of trace elements in other hot springs reported by Young et al. (2014), Seite (2013), Moeni et al. (2014) and Lund (2000) are mostly higher than those in Batu 16. However, the $\mathrm{Si}$ concentration in Batu 16 is higher than those in the Hae-Un-Dae and La Roche-Posay hot springs. Furthermore, the Ni concentration in Batu 16 is higher than those in the five hot springs in Mahallat, Central Iran and Arkansas. Meanwhile, the $\mathrm{K}$ concentration in
Batu 16 is higher than those in the five hot springs in the Mahallat, Arkansas and La Roche-Posay hot springs. For the other hot springs in the study area (Table 6), SL 2 has higher Mn content than Romatism and Hakim hot springs.

Although the concentrations of other trace elements in the study area are slightly low compared to those of Dash et al. (2013); Hamzah et al. (2013); Mohd Hasni et al. (2017); Okpokwasili et al. (2013); Olivier et al. (2008); Prakash et al. (2017); Shahub et al. (2016); Singh et al. (2014); Singh and Sunayana (2017), it does not affect the health benefits of these hot springs because a small amount of these constituents is sufficient to treat certain skin illnesses. High concentrations of certain chemical constituents do not signify better absorption or health benefits (Javed et al. 2009; Matz et al. 2003). Bacle et al. (1999) reported that skin comfort, which includes skin softness and suppleness, is better achieved with waters that contain low mineral concentrations. Bacle et al. (1999) hypothesised that low salt concentration tends to remain longer when in contact with skin because it has high surface tension and evaporate slower, which result in better hydration and moist skin. Another factor that influences mineral absorption rate is the skin membrane structure controlling the movement of water entering and exiting the body (Javed et al. 2009; Matz et al. 2003).

Numerous studies have documented the health benefits of chemical compounds in hot springs. Table 7 summarises some of the therapeutic effects of trace elements found in Hulu Langat hot springs.

TABLE 6. Trace elements content in Hulu Langat hot springs as compared to the renowned balneotherapeutic hot springs worldwide

\begin{tabular}{|c|c|c|c|c|c|c|c|c|c|c|c|c|c|c|}
\hline \multirow{2}{*}{$\begin{array}{c}\text { Trace } \\
\text { Element }\end{array}$} & \multirow{2}{*}{ Batu 16} & \multirow{2}{*}{$\begin{array}{l}\text { Young et al. } \\
\text { (2014) } \\
\text { (1) }\end{array}$} & \multirow{2}{*}{$\begin{array}{l}\text { Seite } \\
(2013) \\
(2)\end{array}$} & \multicolumn{6}{|c|}{ Moeini et al. (2014) } & \multicolumn{5}{|c|}{ Lund (2000) } \\
\hline & & & & (3) & (4) & (5) & (6) & (7) & (8) & (9) & $(10)$ & (11) & (12) & (13) \\
\hline $\mathrm{Si}$ & 45.3126 & $29.9 \pm 2.7$ & - & 40.46 & - & - & - & - & - & - & - & - & - & - \\
\hline $\mathrm{Li}$ & 0.1071 & $0.4 \pm 0.1$ & - & - & - & - & - & - & - & - & - & - & - & - \\
\hline $\mathrm{Fe}$ & 0.0163 & $0.0 \pm 0.0$ & - & 1.2 & 0 & 0 & 0 & 1.31 & 1.14 & - & - & - & - & - \\
\hline $\mathrm{Pb}$ & 0.0001 & $0.0 \pm 0.0$ & - & 11 & 24 & 10 & 6 & 0 & 2 & - & - & - & - & - \\
\hline Mn & 0.0026 & $0.0 \pm 0.0$ & - & 0.04 & 0.14 & 0.01 & 0 & 0.04 & 0.05 & - & - & - & - & - \\
\hline $\mathrm{Ni}$ & 0.0008 & - & - & - & - & - & - & - & - & - & - & - & - & - \\
\hline $\mathrm{Se}$ & 0.0002 & - & 0.053 & 0 & 1 & 0 & 0 & 0 & 0 & - & - & - & - & - \\
\hline $\mathrm{Ag}$ & -0.0002 & - & - & 0.46 & 0.24 & 0.81 & 0 & 0 & 0 & - & - & - & - & - \\
\hline $\mathrm{Na}$ & 228.1836 & $839.5 \pm 158.9$ & - & 80.96 & 80.96 & 74.52 & 87.63 & 80.96 & 74.52 & 4 & 326.2 & 520 & 690 & 290 \\
\hline $\mathrm{Zn}$ & 0.0158 & $0.1 \pm 0.0$ & $<0.005$ & 3.51 & 251.1 & 1.51 & 2.79 & 0.87 & 0.86 & - & - & - & - & - \\
\hline $\mathrm{K}$ & 3.3885 & $27.2 \pm 8.60$ & $<0.005$ & 1.95 & 1.95 & 1.95 & 2.34 & 1.95 & 1.95 & 1.5 & 89.6 & 82 & 15 & 0.08 \\
\hline $\mathrm{Mg}$ & 0.0374 & $2.1 \pm 0.4$ & 4.4 & 38.4 & 19.2 & 37.2 & 75.6 & 48 & 49.2 & 4.8 & 121.6 & 38 & 0.2 & 0.08 \\
\hline $\mathrm{Ca}$ & 0.4572 & $517.3 \pm 91.4$ & - & 149 & 374 & 420 & 384 & 390 & 376 & 45 & 624 & 150 & 210 & 34 \\
\hline $\mathrm{Al}$ & 0.0472 & $0.0 \pm 0.0$ & - & 0 & 0.48 & 0 & 0 & 0 & 0 & - & - & - & - & - \\
\hline As & 0.0192 & - & - & 19.2 & 13 & 5.49 & 5.68 & 21.4 & 18.5 & - & - & - & - & - \\
\hline $\mathrm{Ba}$ & 0.0015 & - & - & 0.02 & 0 & 0 & 0 & 0.02 & 0.02 & - & - & - & - & - \\
\hline $\mathrm{Cd}$ & 0.0000 & - & - & 0 & 0.52 & 0 & 0 & 0 & 0 & - & - & - & - & - \\
\hline $\mathrm{Cr}$ & 0.0026 & - & - & 0 & 0.13 & 0 & 0.02 & 0 & 0 & - & - & - & - & - \\
\hline $\mathrm{Cu}$ & 0.0017 & $0.0 \pm 0.0$ & - & 1.61 & 33.1 & 0.39 & 0.67 & 0.4 & 0 & - & - & - & - & - \\
\hline
\end{tabular}

Note: South Korea (1) Hae-Un-Dae; France (2) La Roche-Posay Thermal Spring Water; Mahallat Spring, Central Iran (3) Shafa (4) Soleimani (5) Romatism (6) Hakim (7) Donbe (8) Soda (Bakhtiari); USA (9) Hot Springs, Arkansas (10) Thermopolis, Wyoming (11) Indian Springs, Colorado (12) Belkap Spring, Colorado (13) Desert Hot Springs, California 
TABLE 7. The example of chemical elements in hot springs that attributed to the health benefits

\begin{tabular}{|c|c|}
\hline Element & Medicinal benefits \\
\hline $\begin{array}{l}\text { Sodium }(\mathrm{Na}) / \text { Sodium carbonate/ } \\
\text { Sodium hydrogen carbonate }\end{array}$ & $\begin{array}{l}\text { Alleviates rheumatism, nervous system diseases, postoperative disorders, gynaecological diseases, } \\
\text { lymphatic system, athlete's foot, arthritis, gastrointestinal disorders, skin disease and neuralgia; } \\
\text { lowers blood pressure and cardiac stress; beautifies the skin; accelerates tissue regeneration, promotes } \\
\text { metabolism and blood circulation; and treats gastrointestinal disorders, cholecystitis, neuralgia, } \\
\text { arthritis, external injury, liver disease, allergies, chronic skin disease and measles. }\end{array}$ \\
\hline Magnesium (Mg) & Alleviates heart diseases and psoriasis; promotes healthy bones teeth, skin and nervous system \\
\hline Potassium $(\mathrm{K})$ & $\begin{array}{l}\text { Alleviates heart diseases and psoriasis; promotes healthy bones, teeth and skin; normalises heart } \\
\text { rhythms; reduces high blood pressure; removes body toxins }\end{array}$ \\
\hline Zinc $(\mathrm{Zn})$ & Heals psoriasis \\
\hline Silica \& fluorine (Si and F) & Promotes cardiovascular health and bone remineralisation \\
\hline Ferrous $(\mathrm{Fe})$ & Cures anaemia, women's diseases, menopause problems, chronic eczema and treats fatigue. \\
\hline Calcium $(\mathrm{Ca})$ & Cures foot/leg cramps and menstrual and menopause problems \\
\hline Lithium (Li) & Mood disorder \\
\hline Manganese (Mn) & Antioxidant, metabolism and thyroid, fatigue \\
\hline Silver & Antibacterial \\
\hline
\end{tabular}

Source: Modified from Markiey et al. (2005); Moeini et al. (2014); Peninsular Hot Spring (2013); Crystal Hot Spring (n.d)

\section{LIMITATION OF THE STUDY AND SUGGESTION FOR FUTURE STUDIES}

Sulphur was not analysed due to the unavailability of the substance's standard to run the test, the restriction to enter the site for sample recollection, and the strict duration to retain the old samples for accurate analysis. Moreover, samples collected from different time may have produced different results. Future studies should conduct actual testing of the medicinal properties of hot spring water on patients with skin issues.

Given these hot springs, the study area has a great potential to become a geotourism area. Thus, a geoitinerary that highlights the geological importance with related activities and available facilities of those sites needs to be developed if geotourism is considered (Rapidah et al. 2018a, 2018b). At present, the Sg. Serai and Sg. Lalang (in Semenyih) Hot Springs have been classified as geofeature sites based on the suggested ranking in the study by Yusry et al. (2018).

\section{CONCLUSION}

The hot springs in the study area are classified according to their $\mathrm{pH}(6.83-8.71)$ and temperature. The lowest temperature $\left(40.47^{\circ} \mathrm{C}\right)$ was recorded in the Dusun Tua hot spring, whereas the highest temperatures $\left(70.41-74.03^{\circ} \mathrm{C}\right)$ were observed in the IKBN hot springs. All hot springs in the study area can be classified as hyper thermal.

Compared with the other geothermal sites, Batu 16 hot spring contains higher concentrations of $\mathrm{Si}, \mathrm{Li}, \mathrm{Na}$, $\mathrm{K}$, As and $\mathrm{Cu}$. However, the concentrations of $\mathrm{Fe}$ and $\mathrm{Ca}$ are higher in the Sg. Serai and Sg. Lalang hot springs, and the highest concentration of $\mathrm{K}$ is found in Dusun Tua.

Given the abundance of trace elements, the hot springs in the study area are comparable to other internationally recognised hot springs with therapeutic effects. Although further investigations are warranted, the hot springs in the study area have high potential to be established as important geological sites in the future not only for health and recreational purposes but also for geotourism.

\section{ACKNOWLEDGEMENTS}

We would like to acknowledge the funding provided by Universiti Kebangsaan Malaysia under the university research grant GUP-2017-083 and FRGS/1/2014/ STWN06/02/4.

\section{REFERENCES}

Ablin, J.N., Hauser, W. \& Buskila, D. 2013. Spa treatment (Balneotherapy) for fibromyalgia-A qualitative-narrative review and a historical perspective. Evidence-Based Complementary and Alternative Medicine http://dx.doi. org/10.1155/2013/638050. Accessed on 22 February 2019.

Atiqah, A., Syafawanie, A., Syafiqah, A., Izhar, I., Zarif, M., Abdelazim, A., Syafiq, A. \& Ong, Q.W. 2017. Hydrogeological and environmental study of Sungai Serai, Hulu Langat. Pakistan Journal of Geology 1(1): 8-11.

Anua, N.A. 2014. Geology and development of geothermal source potential map based on regional lineament density and thermal map around Hulu Langat, Selangor. BSc. Thesis, Geology Program, Universiti Kebangsaan Malaysia (Unpublished).

Bacle, I., Meges, S., Lauze, C., Macleod, P. \& Dupuy, P. 1999. Sensory analysis of four medical spa spring waters containing various mineral concentrations. Int.J.Dermatol.38: 784-786.

Baioumy, H., Nawawi, M., Wagner, K. \& Arifin, M.H. 2015. Geochemistry and geothermometry of non-volcanic hot springs in West Malaysia. Journal of Volcanology and Geothermal Research 290: 12-22.

Bryan, K. 1919. Classification of springs. Journal of Geology 27(7): 522-561. 
Chakrabarty, P. \& Mandal, R. 2018. Geotourism mapping for sustainability: A basin oriented approach. Geojournal of Tourism and Geosites 21(1): 174-185.

Crystal Hot Spring. n.d. Mineral Benefits.

Health $\% 20$ Benefits $\% 20$ of $\% 20$ Hotspring/Minerals $\% 20$ Benefits \% 20_\%20Crysta1\%20 Hot $\% 20$ Springs_ withconcentration.htm. Accessed on 15 September 2016.

Dash, A., Palita, S.K. \& Patra, H.K. 2013. Physico-chemical analysis of thermal spring of Atri in the district of Khurda, Odisha, India. International Journal of Chemical Sciences and Applications 4(2): 97-104.

Department of Sustainability, Environment, Water, Population \& Communities. 2012. Salinity \& Water Quality. Canberra: Department of Sustainability, Environment, Water, Population $\&$ Communities

EPA. 2001. Parameters of Water Quality: Interpretation and Standards. Wexford: Environmental Protection Agency.

Erfurt-Cooper, P. 2010. Geotourism in Volcanic and Geothermal Environments: Playing with Fire? Geoheritage 3: 187-193. DOI: $10.1007 / \mathrm{s} 12371-010-0025-6$.

Finkelman, R.B. 2006. Health benefits of geologic materials and geologic processes. International Journal of Environmental Research and Public Health 3(4): 338-342.

Gill, J.C. 2017. Geology and the sustainable development goals. Episodes 40(1): 70-76.

Golusin, Z., Jovanovic, M., Jeremic, B. \& Jolic, S. 2014. Balneotherapy of psoriasis. Serbian Journal of Dermatology and Venereology 6(3): 105-112.

Hamzah, Z., Abd Rani, N.L., Saat, A. \& Wood, A.K. 2013. Determination of hot springs physic-chemical water quality potentially use for balneotherapy. The Malaysian Journal of Analytical Sciences 17(3): 436-444.

Javed, A., Iqbal, J., Asghar, U., Khan, F.A., Munshi, A.B. \& Sddiqui, I. 2009. A study to evaluate therapeutic properties of minerals of Manghopir Hot Sping, Karachi. J. Chem. Soc. Pak. 31(3): 396-401.

Kamal Roslan Mohamed. 1999. Geologi Semenanjung Malaysia: Stratigrafi Jalur Barat. Bangi: Universiti Kebangsaan Malaysia (unpublished).

Kuleta, M. 2018. Geodiversity research methods in geotourism. Geosciences 8(197): 1-9. DOI: 10.3390/geosciences8060197.

Lund, J.W. 2000. Balneological use of thermal water in the USA. GHC Bulletin. pp. 31-34. https://oregontechsfstatic. azureedge.net/sitefinity-production/docs/default-source/ geoheat-center-documents/quarterly-bulletin/vol-21/art10. pdf?sfvrsn=34298d60_4. Accessed on 3 March 2019.

Matz, H., Orion, E. \& Wolf, R. 2003. Balneotherapy in dermatology. Dermatologic Therapy 16: 132-140.

Markiey, C.K., Tong Pei, S., Lan Huang, H., Yin Pan, Y., Jie Guo, Y. \& Lin Chen, Y. 2005. Developing the culture of Beitou Hot Spring. Applied English Department: Kun Shan University of Technology: 29.

Minerals and Geoscience Department of Malaysia. 1985. Geological Map of Peninsular Malaysia $(1: 500,000), 8$ th Ed. Minerals and Geoscience Department of Malaysia.

Moeini, V., Moore, F. \& K'tso, N. 2014. Characterization of balneological properties of Mahallat Thermal Springs, Central Iran. Acta Balneologica 1(135): 27-32.

Mohd Hasni, J., Aminnuddin, M., Ariza, Z., Azwani, A., Engku Nurul Syuhadah, E.A., Nor Asikin, J. \& Nor Dalila, M. 2017. Comparison of heavy metal levels in natural spring and bottled drinking water in Klang Valley, Malaysia. Malaysian Journal of Public Health Medicine 17: 46-50.
Newsome, D. \& Dowling, R.K. 2006. The scope and nature of geotourism. In Geotourism, edited by Dowling, R.K. \& Newsome, D. Massachusetts: Elsevier ButterworthHeinemann. pp. 3-25.

Okpokwasili, G.C., Douglas, S.I. \& Inengite, A.K. 2013 Seasonal variations of some physicochemical parameters of groundwater in crude oil flow stations. Journal of Environmental Science and Water Resources 2(1): 16-21.

Olivier, J., van Niekerk, H.J. \& van der Walt, I.J. 2008. Physical and chemical characteristics of thermal springs in the Waterberg area in Limpopo Province, South Africa. Water SA 34(2): 163-174.

Peninsular hot spring. 2013. Peninsular Hot Springs. www. peninsularhotsprings.com/uploads/files/.../Media\%20kit\%20 August \%202013.pdf. Accessed on 16 August 2016.

Prakash, P., Gupta, B.K. \& Ahmad, M.F. 2017. Characteristics of hot water springs in a region of Rishikund Munger district of Bihar State, India. International Research Journal of Environmental Sciences 6(10): 15-21.

Raisbeck, M.F., Riker, S.L., Tate, C.M., Jackson, R., Smith, M.A., Reddy, K.J. \& Zygmunt, J.R. 2008. Water Quality for Wyoming Livestock \& Wildlife: A Review of the Literature Pertaining to Health Effects of Inorganic Contaminants. Wyoming: University of Wyoming.

Rapidah,M.S., Mohamed, K.R.,Ali,C.A.,Leman, M.S. \& Saidin, M. 2018a. A geotouristic itinerary: A proposal for geotourism and archaeotourism development of Lenggong Valley, Perak, Malaysia. GeoJournal of Tourism and Geosites 22(2): 597624. https://doi.org/10.30892/gtg.22227-314.

Rapidah, M.S., Mohamed, K.R.,Ali, C.A.,Leman, M.S. \& Saidin, M. 2018b. The application of market appeal-robusticity matrix: A case study of the archaeological heritage of Lenggong Valley, Perak, Malaysia. GeoJournal of Tourism and Geosites 23(3): 702-718. https://doi.org/10.30892/ gtg.23307-321.

Reyes, J.N., Jaramillo, M.E., Soriano, A.O. \& Romero, I.V. 2015 Physical-chemical and therapeutic properties of hot springs and hydrothermal waters. International Journal of Research and Innovations in Earth Science 2(1): 1375-2394.

Rosca, M. 2003. Geothermal energy and therapy uses in Romanian spas. IGC2003 - short course, Geothermal Training Programme. pp. 99-117.

Sahin-Onat, S., Tasoglu, O., Ozisler,Z., Guneri, F.D. \& Ozgirgin N. 2015. Balneotherapy in the treatment of knee osteoarthritis: A controlled study. Arch. Rheumatol. 30(4): 292-297.

Seite, S. 2013. Thermal waters as cosmeceuticals: La RochePosay thermal spring water example. Clinical, Cosmetic and Investigational Dermatology 6: 23-28.

Shahub, M.S., Ibrahim, M.S., Algammal, M.I., Abdelgalil, M \& Alatrash, M.S. 2016. IOSR Journal of Environmental Science, Toxicology and Food Technology 10(6): 46-50.

Sherpa, M.T., Das, S. \& Thakur, N. 2013. Physicochemical analysis of hot water springs of Sikkim-Polok Tatopani, Borong Tatopani and Reshi Tatopani. Recent Research in Science and Technology 5(1): 63-67.

Singh, S., Negi, R.S. \& Dhanai, R. 2014. A study of physicochemical parameters of springs around Srinagar Garhwal valley, Uttarakhand. International Journal of Engineering Development and Research 2(4): 3885-3887.

Singh, S.P. \& Sunayana. 2017. Study of physico-chemical parameters of groundwater quality of Indira Nagar, Gorakhpur. Journal of Civil Engineering and Environmental Technology 4(5): 416-422. 
Subtavewung, P.H., Raksaskulwong, M. \& Tulyatid, J. 2005. The characteristic and classification of hot springs in Thailand. Proceedings World Geothermal Congress. Antalya, Turkey, 24-29 April.

Tanyatanaboon, B. \& Penkar, R. 2016. Health \& Wellness Industry Report - Issue 2: Thermal Hot Springs. Horwath HTL http://country-clone.htl-web.com/files/2016/06/HWThermal-Hot-Spring.pdf.

UKHCA. 2016. Controlling Scalding Risks from Bathing and Showering. Sutton: United Kingdom Homecare Association Ltd.

White, D.E. \& Brannock, W.W. 1950. The sources of heat and water supply of thermal springs, with particular reference to Steamboat Springs, Nevada. Eos, Transaction American Geophysical Union 31(4): 566-574. https://doi.org/10.1029/ TR031i004p00566.

Young, B.L., Jun, Y.L., Hye, J.L., Seong, T.Y., Jong, T.L., Hong, J.K., Dong, S.Y., So, Y.W. \& Jin, W.K. 2014. Immunomodulatory effects of balneotherapy with Hae-UnDae thermal water on imiquimod-induced psoriasis-like murine model. Ann. Dermatol. 26(2): 221-230.

Yusry, M., Simon, N. \& Unjah, T. 2018. Geodiversity and geoheritage assessment in Hulu Langat District, Selangor, Malaysia. GeoJournal of Tourism and Geosites 23(3): 861872. https://doi.org/10.30892/gtg.23320-334.
Norbert Simon*, Tanot Unjah \& Muzaffar Yusry Institute for Environment and Development (LESTARI) Universiti Kebangsaan Malaysia 43600 UKM Bangi, Selangor Darul Ehsan Malaysia

Norbert Simon* \& Muhammad Ashahadi Dzulkafli Center for Earth Science and the Environment Faculty of Science \& Technology Universiti Kebangsaan Malaysia 43600 UKM Bangi, Selangor Darul Ehsan Malaysia

Norbert Simon*

Natural Disaster Research Center

Faculty of Science and Natural Resources

Universiti Malaysia Sabah, Jalan UMS

88400 Kota Kinabalu, Sabah

Malaysia

*Corresponding author; email: norbsn@ukm.edu.my

Received: 26 March 2019

Accepted: 15 August 2019 